changes in the interpretations given to the robot's behaviour; for instance, a pleasant smile executed at half-speed appeared as ugly and menacing. Obviously, it would have been a relatively simple matter to provide the robot with artificial tear-glands, the tear-ducts being opened only when the appropriate facial expression was being displayed. Frude points out that future tearful statues of the Virgin could appear even more miraculous than any past attempts at religious trumpery.

"Trumpery" here is my term, not Frude's. In general, he is curiously coy about the moral evaluation of these predicted developments, or at least sees this as more ambiguous than many others would. He forecasts the end of social isolation, when people can buy " $a$ friend off the shelf", and the alleviation of domestic suffering given the widespread use of programmed marriage-counsellors and antisuicidal Samaritans. Religious and political persuasion and counselling, too, will be available, untouched by human hand. He does not seem to be speaking with tongue in cheek: there is hardly a suggestion that the "social" communication and "religious" counselling he mentions are different in principle from those we enjoy today. There will of course be some deficiencies in practice, due to insufficient advances in the technology; but these, he says, will be largely compensated for by the human users - much as we compensate for the abnormal speech of a foreigner, or of a laryngectomy patient. And he repeatedly rebuts the general question of whether intimate computers should be written, always with the claim that irresistible commercial pressures will make them widely available, whether we like it or not.

The general reader may be misled into believing that an impressive artificial intelligence is only just around the corner. Some forward-looking businessman, dazzled by Frude's forecasts of vast profits, may even rush to beg a loan from his nearest merchant-banker - though, bankers being cautious characters, his mission should be fruitless. Neither author sufficiently emphasizes the difficulties involved, the enormous size of the gap between current programs and the human mind. Certainly, Frude does alert his readers to these difficulties every so often. After describing the smiling robot, for example, he points out that "Getting a machine to laugh is easy. Getting it to laugh at a joke is very, very, difficult"'. Berry, by contrast, writes as though the difficulties were negligible, as though our evolutionary replacement by the first non-biological species - a species capable of influencing the nature of the end of time itself - is a clear certainty. But then, seeing a joke may be difficult for human beings, too.

Margaret A. Boden is Professor of Philosophy and Psychology at the University of Sussex. Her books include Artificial Intelligence and Natural Man (Basic Books, 1977).

\section{Thoughts of sorts}

\section{Stuart Sutherland}

Science and Moral Priority: Merging
Mind, Brain, and Human Values.

By Roger Sperry.

Basil Blackwell/Columbia University

Press: 1983. Pp.135. £12.50, \$16.95.

MANY years ago I worked briefly in Professor Roger Sperry's laboratory at Caltech. I was running experiments on goldfish and on cats, and from time to time he would pop his head round the door, enquire "Have you stopped feeding the goldfish to the cats yet?" and disappear with a chuckle. The chuckle quotient of Science and Moral Priority is low, and it is apparent that having won a Nobel Prize for his elegant research on the development of the nervous system and on the split-brain, Sperry has turned his mind to higher things, namely, the nature of consciousness and the selection of moral values. From Charles Sherrington to John Eccles it has been characteristic of neuroscientists to devote their declining years to metaphysical problems. It is also characteristic that they have refused to burden themselves with a knowledge of any previous work on the subject, thus leaving themselves all the freer to speculate. Sperry's new book upholds this tradition.

On the mind-body problem, he adopts a monist position, in which consciousness is an emergent property of the brain. For him, consciousness is made up of complex patterns of activity in the nervous system which apparently can be understood only in mental not physical terms. He believes these patterns of activity are identical to perception, thinking, taking decisions and so on. Since they determine other events in the nervous system and control the muscles, he ascribes to the mind a causal force. He appears to be torn between his scientific view of the brain and his desire to preserve the importance of consciousness, since on page 68 he writes that consciousness is not reducible to neural events whereas on page 96 he states that it is.

Sperry's main and frequently repeated argument for his form of monism, which he modestly describes as a "conceptual breakthrough", is that it constitutes a " paradigm change" that is widely accepted by the informed majority. Leaving aside the danger of deciding truth on a ballot, it is not true that the majority of cognitive and brain scientists, whether informed or not, adopt this view of the nature of consciousness. Most of them are wise enough to hold no view and the fact that the phenomena of consciousness have received increased attention over the past 30 years has nothing to do with anyone's opinions of their status. Indeed, Sperry does not attempt to specify how this "paradigm change" has actually influenced scientific research on cognition and the brain, nor could he do so since, provided consciousness is in some way linked to brain activity, its status is irrelevant. $\mathrm{He}$ is right in thinking that any higher-level system can be explained only in terms of concepts appropriate to that level: the behaviour of molecules cannot be explained solely in terms of the concepts that apply to individual atoms nor can the computations carried out by a program be explained solely in terms of transistors. But this merely reflects a limitation of the human mind, which cannot manipulate a large number of separate entities at once and which must therefore construct higherlevel concepts in order to apprehend highlevel systems that arise from the interactions of more basic entities. Moreover, Sperry's conclusion that the workings of the brain can only be explained in terms of conscious processes is incorrect. It is at present wholly unclear whether the everyday concepts used to describe consciousness will turn out to be the most appropriate ones to apply to higher levels of organization in the nervous system.

Despite his defiance of William James's sensible injunction that "Dualism is a fundamental datum. Let no man join together what God has put asunder", Sperry is honest enough to admit that his thesis has no empirical support, though he resists the implication that it has no consequences empirical or otherwise. Unfortunately, the only consequences he specifies turn out to be vague promises. According to him, his view of consciousness will "logically dissolve ... the classic fact-value and naturalistic fallacies of philosophy" (whatever they are). Sperry believes that his identity theory of consciousness and brain states (which incidentally is hardly new) will not only make philosophers redundant, it will allow brain scientists to take their place, for the influence of his theory has apparently been such that neuroscience is no longer "dehumanizing": hence the way is open to found human values "on a reference framework based on empirical evidence and the scientific method". $\mathrm{He}$ gives two main arguments for this curious view.

First, he believes that since science has proved the most successful method for discovering empirical truth, it must also be the best way to select moral ends. Even the premise of this non-sequitur may be doubted, since there are many kinds of truth and it could be argued that literature has implicitly revealed much more important truths about human values than has the scientific study of man. Moreover, Sperry does not disclose how science can reveal moral ends. $\mathrm{He}$ adopts, without acknowledgement, a rather broader version of C.H. Waddington's view that it is morally right to promote the ends (whatever they are) of evolution. Sperry talks about the "upward thrust" of evolution, without realizing that the word "upward" implies a value judgement that cannot be derived merely from the scientific study of evolution. He seems to include in evolution 
not only the animal kingdom, but the planetary system and the cosmos itself. $\mathrm{He}$ provides only one example of a moral value derived from science and that is the preservation of the biosphere. Although it has taken science to discover - and to some extent create - the threat to the biosphere, anyone, however unscientific, who is concerned about the future of life will readily agree that the biosphere should be preserved. Scientific findings may both point to dangers and provide means by which conditions can be either ameliorated or made worse, but they are irrelevant to the question of ultimate ends. It is unclear, for example, how science would resolve such ethical problems as abortion; Sperry himself notes that it is a way of reducing overpopulation, but this oversimplifies the problem and there are many other ways of reducing population growth.

A second reason he adduces for the importance of science is that "a science of values in the context of decision theory becomes conceivable". He hints that scientists may one day find methods of forming and controlling people's values. Any such development, which fortunately is extremely remote, is likely to create more moral problems than it solves. Sperry does not stop to consider who would control the use of such methods or the consequences of their being abused. Nor does he recognize

\section{IMAGE \\ UNAVAILABLE FOR COPYRIGHT REASONS}

that much of the trouble in the world is created not because people have wrong values, but because they fail to act in accordance with the moral values they have. Indeed, so great is his enthusiasm for science that he ignores all the problems that fundamental discoveries about ourselves might bring. Where there is a plausible causal account of an action (for example, if it can be attributed to schizophrenia or a brain tumour), we no longer hold the agent responsible. What would happen to the idea of responsibility if Sperry's science of values were sufficiently developed to explain in causal terms the values held by everyone?

It will be apparent that this is a disappointing book. It consists of disconnected essays, whose tiresome repetitions serve the place of argument. There are too many arguments by assertion, too many unsubstantiated and unillustrated claims, and too many vague promises. Although Sperry casts himself in the role of a prophet, he is disappointingly short of revelations. Moreover, he has a ponderous style that conceals what he is trying to say: he writes, for example,

This derives in part from the conviction that the functional organization of our cerebral machinery is intrinsically such that the scientific method offers the most reliable means by which

\section{Trouble at t'lab}

\section{Walter Gratzer}

\section{Betrayers of the Truth: Fraud and Deceit} in the Halls of Science.

By William Broad and Nicholas Wade. Simon \& Schuster: 1983. Pp.256. \$14.95.

STORIES of heroic deeds in the laboratory act on the reading public like chloroform. Science becomes news when a microbiology technician catches bubonic plague or a professor is set on by a rampaging mob of anti-vivisectionists. Scientific fraud is a subject that has featured widely in science reporting of late, helped by the illsuppressed embarrassment and indignation of the scientific establishment at the intrusion of the outside word into a private grief. The description in the opening chapter of Betrayers of the Truth of the inept attempts of a group of scientific mandarins, brought before a congressional committee on the subject, to get the toothpaste back in the tube is sheer bliss.

William Broad and Nicholas Wade have put together a most captivating book. We are most of us voyeurs, and nothing engenders so much prurient fascination as a gross and indecent violation of the rules by which we are expected to regulate our working lives. Throw in the accompanying discomfiture of stout and dignified parties in positions of authority, and you have all the components of what makes news on a wider stage.

Broad and Wade's purpose, however, is more than just to entertain, for they believe that a close study of the pathology of science will reveal aspects of its normal function that might otherwise remain hidden. Their thesis is that the scientific process is no more informed by reason and objectivity than are other human occupations, that it owes more than is generally conceded to cultural prejudice and rhetorical convention, and that even the best scientists employ in the pursuit of truth a mixture of motives and methods, many of which may not bear close scrutiny. This is not of course the first time that propo- a brain can arrive at an operationally valid stance in the realm of values, as elsewhere.

I think this means "I believe that because of its organization the brain can best discover true values by using the scientific method". To borrow some of his favourite words, his book presents a holistic, mentalist, nonreductive, emergent, dynamic, configurational perspective, but, for myself, I cannot help looking back with nostalgia to the days when Sperry's concerns were with more practical matters, like feline ichthyophagy.

Stuart Sutherland is Director of the Centre for Research on Perception and Cognition at the University of Sussex.

sitions of this nature have been expounded, but Broad and Wade go on to argue that the conventional wisdom about how science works is shown up for a shallow and meretricious conflation by the response of the system to fraud. They are concerned particularly to refute the often heard assertion that falsehood is rapidly eliminated through its failure to meet the criterion for all publishable work, namely that it must be capable of reproduction in other laboratories. In most of the case histories given in the book, the fraud was indeed not exposed by this mechanism. Most commonly it was uncovered accidentally, but more often, it seems to me, than Broad and Wade allow, a gamey smell issuing from published descriptions of the results was picked up by sensitive noses early enough to save expenditure of useless effort.

Leaving aside a number of now celebrated (though still perplexing) historical cases, in which discoverers of great truths (Ptolemy, Newton, Mendel and more recently it seems R.A. Millikan) apparently felt impelled to give their experimental observations a furtive helping hand, the frauds in areas of major importance described by Broad and Wade - xenografting, for example, and the mechanism of malignant transformation by a viral gene - tended to be quickly detected. This has not been so in that vast undergrowth of science, in which the sole criterion of accomplishment is publication, and the products are phantom papers in the sense that they are probably read by no one at all and will never be cited. One of the most remarkable cases in the book concerns a young postdoc, who perpetrated a series of exceptionally cool frauds while working at Harvard Medical School, and during his two years there produced one hundred publications. Can anyone doubt that the outcome of such proceedings must at best be trivial, and that it scarcely matters whether conscious deception plays any part in them? One might argue that the same holds for much of the output in the "soft" sciences - prudence deters me from being too specific - in which all results tend to reduce to the basic form "some do, some don't". 